\title{
'n Woordaangedrewe vaartuig: Susan Smith se eko-digkuns
}

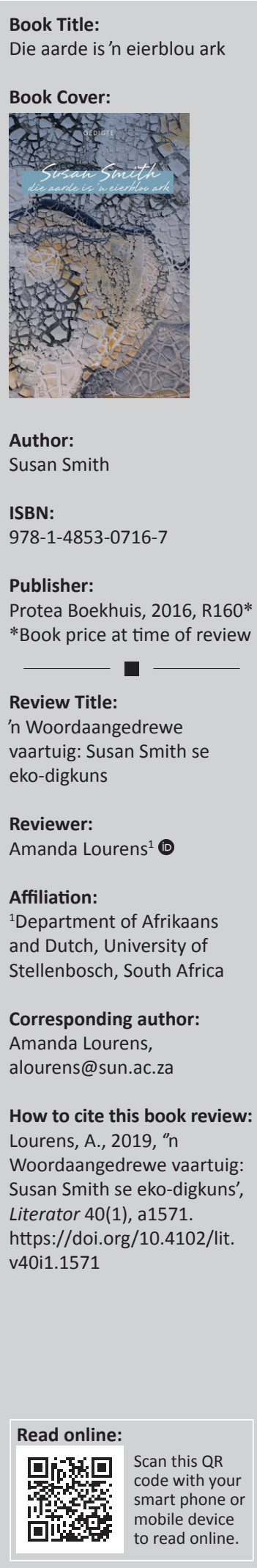

Susan Smith is akademikus én digter, en in 2012 debuteer sy as digter met In die afwesigheid van sin, 'n bundel waarin die vroulike ervaring sentraal staan. In hierdie bundel is dit duidelik dat sy haar betrokkenheid by die feministiese literatuurteorie ook in haar kreatiewe werk laat neerslag vind, en 'n soortgelyke tendens is in haar jongste bundel, Die aarde is 'n eierblou ark (2016), sigbaar. Dit is naamlik Smith se akademiese werk binne die veld van die ekokritiek wat die agtergrond vorm vir hierdie bundel gedigte oor die natuur, maar by uitstek oor die mens se verhouding daarmee.

Die basiese veronderstelling waaromheen die digter die bundel opbou, is dat die aarde nie net die mens se verblyf is nie, maar ook 'n vaartuig of selfs oorlewingstuig in die uitspansel; die tuig vir die mens se lewensreis, en dan wel een wat deur taal en spesifiek die digter se woorde, voortgestu word. Terselfdertyd is die aarde as menslike ruimte egter ook 'n saad wat die moontlikheid van woorde en betekenis - en dus sin - daarin bevat, soos blyk uit 'Eierblou ark' (bl. 12):

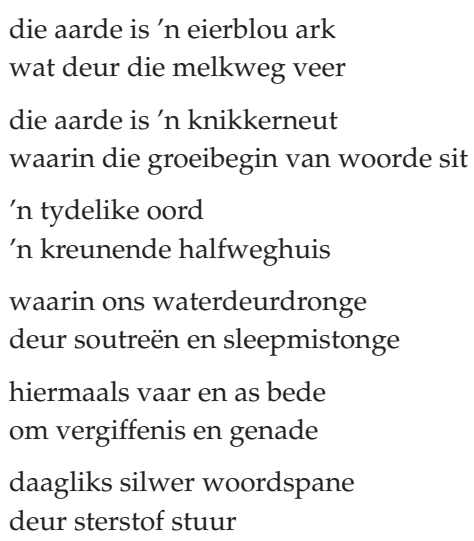

In hierdie reis is daar ' $n$ deurlopende bewussyn van die groter ordeningsbeginsel van die kosmos, wat in die uiters knap 'Credo van die vibrerende materie' (bl. 36) gestalte verkry. Hierdie credo van 'n universele eenheidsgedagte word op mistiek-konkrete wyse soos volg verwoord:

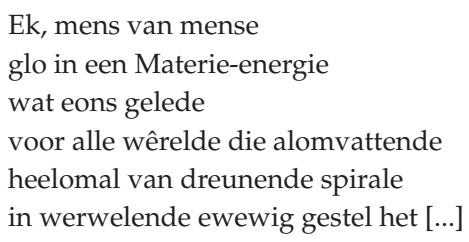

Die bundel balanseer voortdurend op die spilpunt tussen die kosmiese en die aardse, alhoewel laasgenoemde - die 'hiermaals' - die voorkeur geniet, soos in die slotstrofe van 'Credo ...' genoem word: 'Ek is een met haar en hare / daar is net hierdie een aarde.'

Vanuit hierdie oortuiging dig Smith oor die lewensreis, wat vir haar sterk aan die kreatiewe proses verbonde is, maar terselfdertyd vanuit verskillende inkarnasies - waaronder plante, en veral bome beleef word. (Ten opsigte van laasgenoemde vereenselwig sy haar met 'n wortelboom, maar spesifiek in vroulike gedaante, aan die ooskus van Afrika in 'Mangliet', bl. 22). Die saad van Caesalpinia bonduc, oftewel die knikkerneut van die gelyknamige gedig (bl. 29), is 'n verdere belangrike kode. Hierdie sade wat deur die oseane voortgedra word, word as miniatuur-aardes gesien (want ook die saad in 'eierblou ark' is) waaruit daar lewe spruit. Hierdie groeistulp beskik oor die sonderlinge vermoë om ook as lens te dien, waarmee die kosmiese sowel as die aardse betrag kan word, en dit is inderdaad wat in die res van die bundel gebeur: 
die eierblou ark kraak oop

die eerste groeistulp glip deur

'n lens wat visoog na die wêreld kyk

helfte aarde

helfte lug

Oor die wording van die digter word daar besin, en wel aan die hand van die saad-metafoor in 'Saad' (bl. 23-28). Die slotstrofe wys egter op die verskil tusssen die groei van plante en die groei van die gedig - eersgenoemde geskied organies en seisoenaal, terwyl die kunswerk van die skeppende hand van die digter afhanklik is. Die saad-metafoor huisves eweneens die digter se woordvaardige uitbeelding van die liefdesband in 'Vivipaar' (bl. 17):

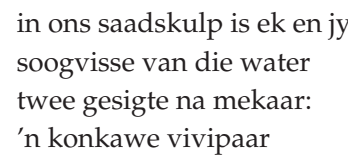

Dit is binne hierdie parameters van aardsheid, vrugbaarheid, groei, beskutting en reis wat Smith haar bundel bou. Sy rig haar oog op die volle spektrum van dinge in die fisiese wêreld sodat sterrestelsels, maar ook die kleinste lewende organismes geregistreer word. Gedigte oor die volheid van die aardse is daar volop, soos dié waarin die lewe van bye en selfs blaarvorme verdig word. In die gedig 'Blaarroetes' (bl. 44) tree die mens as wetenskapsbeoefenaar as die optekenaar van die natuur na vore, alhoewel die metodes van die wetenskap te kort skiet om die werklike inhoud daarvan te peil. Die gedig sluit af met 'n wenk om die natuur sélf hierom te vra, en eindig met 'n 'kroonvlerk' wat goedgunstiglik aan die mens as onderdaan geskenk word om die natuur verder mee te verken. In al hierdie gedigte openbaar Smith haar as 'n belese en denkende subjek te midde van die natuurlike wêreld.

Aan die keersy hiervan is daar gedigte soos die knap 'Aantog van die afkappers' (bl. 45) waarin die mens by wyse van vernietigende werktuie uitgebeeld word, terwyl die boom in 'n menslike gedaante aanskou word, of ook die tekstuurryke 'Renosterveld' (bl. 47-48) waar die landskap as verkragte vrou verbeeld word. 'n Vonds soos 'hoe bloedbelope die binnelies / van die sterrekaroo' in hierdie gedig, ruk die leser aan die strot en open 'n venster op Smith se ontluisterende blik op die mens.

Die gemene deler van al hierdie gedigte is die bewussyn van die aarde en die natuur as die belangrikste anker vir menslikheid, en die ekologies bewuste oproep om die bewaring daarvan, loop deur die bundel.

Telkens wend die digter haar na 'n byna magiese, primordiale, maar steeds lyflike ruimte van waaruit die gedigte voortspruit: Die woord- en beeldgebruik berus dikwels op onbewuste assosiasies waaruit lieflike liriese reëls opklink, soos in die byna virtuoos gekonstrueerde 'Leaves of grass' wat aan Walt Whitman opgedra word. Die gedig ondersoek onder meer die mens se fisieke verbondenheid aan die natuur, maar wat in hierdie gedig 'n besondere sensuele tekstuur verkry, soos veral in die derde strofe gesien word:
[...] jou aarde van beminning en beminde: geen kil rots geen moeder geen godin vir jou nie jy lees die tekens van begeer in die vogtige vingers van die see jy haas jou om in die klam uitruil jou nakend uit te strek

Benewens die sensuele omgang met die aardse, is die mens se eenwording met daarmee 'n verdere tema wat ondersoek word, soos dit in 'Biogenese' (bl. 43) die geval is. In hierdie gedig word die tuin as 'n vroulike entiteit met 'kantrokke / en donker onderklere' geïdentifiseer, soos ook in 'Aantog van die afkappers' die geval is. Die eenwording met die aarde maak aan die een kant 'n nadere kennis van die heelal moontlik wanneer die digter ervaar hoe sy in die spore van groot geeste soos Darwin en Hawking, maar dan ook Noag en Spinoza, haar in onder meer die heelal se ontstaan uit 'n singulariteit verdiep. Aan die ander kant maak dit egter ook 'n reis in die self moontlik, soos wat in 'Onderwater' (bl. 15) verbeel word wanneer die subjek in 'n evolusionêre geheue kan wegsink en vanuit ' $n$ alternatiewe inkarnasie die ware self ontmoet.

Dit is uiteindelik dan die jukstaposisie van die hemelse (soos deur die uitbeelding van die kosmiese verteenwoordig) en die aardse (soos onder meer in die bundel deur die uitbeelding van 'n ondersese wêreld verteenwoordig) wat 'n belangrike kode in die bundel word. Meer as een gedig in die bundel gaan spesifiek met hierdie jukstaposisie om, maar in 'Water (I)' met sy bykans Barokagtige aanslag, word dit selfs verder gevoer om ook 'n eenwording van die kosmiese en ondersese in te sluit, waarin die kreatiewe proses bevat word:

wat die water herhaal

is die roete van die migrerende vis

die swemhale van die immer

ontglippende gedig

Die digter onthul haarself in die bundel as vertroud met die natuurwetenskap en die diskoers van eietydse denkers daaroor. Tog is sy soos Neruda in die motto wat sy aan hom ontleen, die bestekopnemer van natuurlike maar ook van psigiese lotgevalle. Uiteindelik kan die leser nie anders as om te besluit dat die digter haarself as die waarnemende instansie in 'Patryspoort' (bl. 13) eien nie. Soos die sturende instansie in Totius se bekende 'Nag op see', is sy die een met die besef van 'n groter kompas wat die reis na die eindbestemming van die 'Mysterium tremendum' rig.

Die tweede bundel uit ' $n$ digter se pen word nie om dowe neute dikwels die lakmoestoets vir digterskap genoem nie. Smith slaag hierdie toets met vlieënde vaandels, en die bundel toon in der waarheid ook 'n stygende interne lyn van die begin- na die slotgedeelte. Aanvanklik is daar enkele gedigte wat nie heeltemal op dieselfde peil as die res is nie soos byvoorbeeld 'Hearing like a bat' (bl. 38-39) wat deur clichés en 'n mate van oorskrywing ontsier word. Dit is egter 'n klein beswaar teen 'n geheel waaraan 'n blote resensie nie reg kan laat geskied nie. 